\title{
Effects of the Word Frequency and the Phonetic Complexity on Lexical Retrieval in Children with Pure Speech Sound Disorders
}

\author{
Na-Yeon Kim ${ }^{\mathrm{a}}$, Ji-Wan $\mathrm{Ha}^{\mathrm{b}}$ \\ ${ }^{a}$ Department of Speech and Language Pathology, Graduate School of Rehabilitation, Daegu University, Gyeongsan, Korea \\ ${ }^{b}$ Department of Speech-Language Pathology, Daegu University, Gyeongsan, Korea
}

Correspondence: Ji-Wan $\mathrm{Ha}$, $\mathrm{PhD}$

Department of Speech-Language Pathology, Daegu

University, 201 Daegudae-ro, Jillyang-eup,

Gyeongsan 38453, Korea

Tel: $+82-53-850-4327$

Fax: +82-53-850-4329

E-mail: jw-ha@daegu.ac.kr

Received: October 21, 2018

Revised: November 16, 2018

Accepted: November 16, 2018

This work was supported by the National Research Foundation of Korea Grant Funded by the Korean Government (NRF-2017R1C1B1010913).
Objectives: The current study aims to compare the lexical retrieval ability between children with pure speech sound disorders (pure SSD) and typically developing children (TD). This study also examines the influence of word frequency and phonetic complexity on the performance of a lexical retrieval task in SSD and TD groups. Methods: The participants were 20 pure SSD and 20 TD children from 4-6 years old. All participants performed the lexical retrieval task. The total score and error score were analyzed, and the error score was used to diagnosis whether the subjects had a semantic-lexical deficit (S-L deficit) or lexicalphonological deficit (L-P deficit) using the WebFit program. Additionally, their performance was analyzed according to word frequency and phonetic complexity. Results: The pure SSD group showed a significantly lower total score than the TD group. In the types of error, the pure SSD group showed significantly more nonword errors than the TD group. The pure SSD group showed more L-P deficits than TD group in the WebFit program, but the difference between groups were not significant. Both groups showed lower ability in low frequency words compared to high frequency words. Also, both groups showed lower ability in 'high phonetic complexity level than the 'low' phonetic complexity level. However, there were no significant differences between the groups in the phonetic complexity 'high'. Conclusion: The study results indicate that the pure SSD group had lower lexical retrieval ability than the TD group. These results suggest that articulatory and lexical levels are interactive.

Keywords: Speech sound disorder, Lexical retrieval, Word frequency, Phonetic complexity
심리언어학에서 가장 활발하게 연구되어 온주제 중 하나는 어휘 인출에 관한 것으로, 이에 대한 수많은 모델과 가설들은 Levelt (1991)의 구어산출모델을 기반으로 한다. Levelt의 모델에서 구어 산출과정은 기본적으로 개념화부(conceptualization), 형성부(formulation), 조음부(articulation)의 세 단계로 나뉘며, 형성부는 다 시 의미표제어(lemma)와 어휘소(lexeme)로 세분화된다. 개념화부 는 화자가 말하고자 하는 메시지의 의도, 개념, 의미 등을 생성하고 조직하는 단계이다. 의미표제어는 개념화부에서 형성된 의미들과 연결된 추상적 어휘로, 어휘소는 선택된 의미표제어에 해당하는 음운형태로 정의된다. 따라서 개념화부는 전언어 단계(pre-verbal stage), 의미표제어는 어휘 단계(lexical stage), 어휘소는 어휘후 단 계(sublexical stage)라 할 수 있다. 마지막으로 조음부는 머릿속에 서 형성된 어휘형태를 조음기관의 말-운동과정을 통해 말소리들로 형성하여 구어로 산출하는 운동 단계이다(Levelt, 1991; Levelt, Roelofs, \& Meyer, 1999). 전언어, 어휘, 어휘후, 운동 단계와 같이 일련 의 과정들을 거쳐 구어로 산출되기 때문에, 전통적 심리언어학적 관점에서 구어산출은 순차적인 처리과정으로 간주되어 왔다. 이러 한 순차적 처리과정에서는 각 단계 간 경계가 뚜렷하고, 직전 단계 는 바로 인접한 다음 단계에 영향을 미칠 수 있으나, 이전 단계 또는 상대적으로 거리가 먼 단계와는 영향을 주고 받지 않는 것으로 설 
명되었다(Levelt et al., 1999).

그러나 이러한 순차적 처리과정은 이후 연결주의 모델에서 반박 되었다. 연결주의 모델은 구어산출과정에서 이전 단계의 일방적 영 향이 아닌, 이전 단계와 이후 단계의 쌍방향 간 상호영향에 대해 강 조하였다. 즉, 이전 단계의 처리가 완료되기 전 이후 단계의 정보는 이미 활성화되기 때문에, 순차적 순서상 다음 단계로 간주되었던 단계들도 이전 단계에 영향을 줄 수 있다는 것이다(Dell, 1986). 또 한 최근에는 구어산출과정의 여러 하위단계 간 상호작용을 보다 복잡한 관계망으로 설명하는 연구자들을 찾아볼 수 있다(Fink,

Oppenheim, \& Goldrick, 2017; Goldrick et al., 2018; Heisler, Goffman, \& Younger, 2010). 이들은 인접한 단계뿐 아니라 인접하지 않 은 단계 간에도 상호작용이 있음을 강조하였는데, 이를 구어산출 과정의 "비인접 단계의 상호작용효과(long distance interactive effects)"라고 명명하였다. 예를 들어 의미처리 또는 어휘선택의 방해 가 훨씬 이후에 처리되는 조음부에 부정적인 영향을 주어, 조음의 붕괴(breakdown), 조음산출의 변이성, 조음실행 시간의 연장 등 을 초래할 수 있다는 것이다. 구어산출의 최종 단계가 조음부인 만 큼, 비인접 단계의 상호작용효과에 대한 대부분의 연구들은 구어 산출과정의 이전 단계들과 조음처리과정 간 관련성에 주로 초점을 두었다.

이와 같은 비인접 단계의 상호작용효과는 의사소통장애 분야에 시사하는 바가 있다. 언어의 특정 단계에 결함이 있을 경우, 그것은 그 결함만으로 끝나지 않고 다른 단계, 심지어 비인접 단계들에도 부정적인 영향을 줄 가능성을 배제할 수 없다. 반대로 상대적으로 덜 손상되었거나 강점을 보이는 단계, 또는 중재로 그 기능이 향상 된 단계들로 인해 다른 단계들이 긍정적인 영향을 받을 가능성도 기대해 볼 수 있다. 따라서 특정 영역에 결함이 있는 의사소통장애 인을 대상으로 해당 영역이 아닌 다른 영역의 능력을 심층적으로 분석해 볼 필요가 있을 것이다. 이에 본 연구에서는 다른 장애를 동 반하지 않고 말소리산출에만 결함을 보이는 순수 말소리장애 아동 을 대상으로, 이들의 어휘인출능력을 살펴보고자 하였다. 비인접 단계의 상호작용효과에 대한 선행연구들은 단계들의 쌍방향 간 상 호작용을 강조하면서도, 이전 단계가 최종 단계인 조음부에 미치 는 영향에 대해서만 살펴보았을 뿐, 거꾸로 조음부가 이전 단계에 미치는 영향에 대해 살펴본 연구는 찾아보기 어려웠다. 조음부의 결함이 어휘인출 수행에 미치는 영향을 살펴보는 것이 연구의 목적 인 만큼, 본 연구결과는 이에 대한 의문점을 해결하는 데에 도움이 될 것이다.

순수 말소리장애 아동의 어휘인출능력을 살펴보기 위해, 본 연 구에서는 기존의 이름대기과제 방법 대신 Dell, Schwartz, Martin,
Saffran과 Gagnon (1997)이 제안한 어휘인출과제를 사용하였다. 어휘인출과제는 그림이름대기 방법을 사용한다는 점에서 기존 과 제와 동일하지만, 반응을 유도하고 분석하는 방법에 있어 차이가 있다. 어휘인출과제는 대상자로 하여금 그림을 보자마자 떠오르는 단어를 즉각적으로 대답하도록 독려하고, 이름을 모르더라도 단서 를 제공하지 않는다. 즉, 그림을 보자마자 머릿속에서 인출된 어휘 를 측정하는 것이 목적이기 때문에, 대상자가 입 밖으로 산출한 첫 반응을 점수화한다. 따라서 대상자가 스스로 대답을 수정하였더라 도, 수정하기 전 반응을 분석한다. 조음결함 이외에 다른 장애는 동 반하지 않은 것으로 진단받은 순수 말소리장애 아동인 만큼, 표준 화 어휘검사 이외에 어휘인출과제를 실시하여 대상자의 어휘인출 능력을 심층적으로 평가해보는 것은 의미가 있을 것이다.

또한 Dell 등(1997)은 의미-음운(semantic-phonological, SP) 모 델을 적용하여 어휘인출과제 수행 시 대상자가 첫 반응에서 보인 오류들을 분석함으로써, 대상자가 어휘인출 처리과정 중 어떠한 단 계들 간 연결망이 약화되었는지 알 수 있다고 제안하였다. 이들은 어휘인출과정의 연결망을 크게 의미-어휘연결(semantic-lexical connection)과 어휘-음운연결(lexical-phonological connection)로 구분하였고, 오류분석을 통해 이 두 연결 중 상대적으로 연결망이 약한 곳을 밝혀줄 수 있다고 하였다(Budd, Hanle, \& Griffiths, 2011; Dell et al., 1997; Foygel \& Dell, 2000; Ha \& Sim, 2011b). 의미-어휘 연결이 더 약한 경우 의미-어휘결함 집단(semantic-lexical lesion, S-L 집단)으로, 어휘-음운연결이 더 약한 경우 어휘-음운결함 집단 (lexical-phonological lesion, L-P 집단)으로 분류하도록 하였고, 이 러한 분류는 그들이 개발한 WebFit 프로그램을 이용하여 손쉽게 가능하다. WebFit 프로그램은 개발 초기에는 정상 성인의 말실수 를, 이후 실어증 환자의 어휘결함을 분석하기 위해 사용되었으며, 최근에는 의사소통장애 아동들에게도 적용하여 분석결과를 신뢰 할 수 있음을 밝혔다(Budd et al., 2011). 또한 Ha와 Sim (2011b)은 한국어 분석에 WebFit 프로그램을 적용하여 그 타당성을 검증한 바 있다.

앞에서 언급하였듯이 본 연구결과는 조음부가 구어산출과정의 이전 단계에 미치는 영향을 알아보는 데에 도움이 될 것이다. 더 나 아가 조음산출과정 중 말소리장애 아동에게 부담이 되는 요인이 어휘인출에 미치는 영향을 분석해본다면, 이는 조음부와 다른 단 계 간 상호작용 가능성에 대해 더욱 시사하는 바가 있을 것이다. 이 에 본 연구에서는 실험 어휘를 고빈도 어휘와 저빈도 어휘로, 그리 고 조음복잡성이 높은 어휘와 낮은 어휘로 구분하여, 두 어휘목록 간 수행력 차이를 각각 비교해 보고자 하였다. 말소리장애를 초래 한 기저 요인 중 하나로 음운표상 단계의 결함을 언급한 여러 연구 
들을 찾아볼 수 있다(Kim \& Ha, 2014). 음운표상은 Levelt (1991)의 구어산출모델에서 어휘소와 동일한 것으로, 단어빈도효과는 어휘 소에 접근하는 과정에서 발생한다고 알려져 있다(Jescheniak \& Levelt, 1994). 따라서 음운표상에 결함이 있는 말소리장애 아동의 경우, 저빈도 어휘의 어휘소에 접근하는 것은 더욱 부담되는 과제 일 것이다. 또한 조음복잡성은 음운 및 조음적 복잡성을 반영한 지 표이기 때문에, 음운-조음처리과정에 결함이 있는 말소리장애 아 동은 조음복잡성이 높은 어휘의 경우 더욱 어려움을 느낄 것이다. 이와 같은 이유로 본 연구에서는 단어빈도와 조음복잡성이라는 변 수를 분석에 포함하였다.

이상과 같은 본 연구의 연구질문을 정리하면 다음과 같다.

첫째, 두 집단 간 어휘인출과제 총 점수에 차이가 있는가?

둘째, 두 집단 간 어휘인출과제 수행 시 나타난 오류유형의 비율 에 차이가 있는가?

셋째, WebFit 프로그램을 적용하였을 때 두 집단 간 S-L 집단과 L-P 집단의 분포에 차이가 있는가?

넷째, 두 집단 간 단어빈도에 따른 어휘인출 수행력에 차이가 있 는가?

다섯째, 두 집단 간 조음복잡성에 따른 어휘인출 수행력에 차이 가 있는가?

\section{연구방법}

\section{연구대상}

본 연구는 4-6세 일반아동 20명과 순수 말소리장애 아동 20명, 총 40 명의 아동을 대상으로 하였다. 일반아동 집단의 선정 기준은 첫째, 수용·표현어휘력검사(REVT; Kim et al., 2009)에서 수용어 휘 능력이 -1 SD 이상 범주에 속하는 아동, 둘째, 우리말 조음-음운 평가(U-TAP; Kim \& Shin, 2004)의 단어 수준에서 자음정확도가 정상 범위에 속하는 아동, 셋째, 부모 및 교사로부터 감각적, 신경학 적, 신체학적 결함이 없는 것으로 보고된 아동이었다. 순수 말소리 장애 집단은 전문 언어재활사에 의해 다른 동반 장애가 없고 말소 리산출에만 결함을 보이는 순수 말소리장애로 진단받은 아동들이 었고, 선정 기준은 첫째, 수용·표현어휘력검사에서 수용어휘 능력 이 -1 SD 이상 범위에 속하는 아동, 둘째, 우리말 조음·음운평가의 단어 수준에서 자음정확도는 - $2 \mathrm{SD}$ 이하에 속하는 아동, 셋째, 부 모 및 교사로부터 감각적, 신경학적, 신체학적 결함, 인지적 및 언어 적 문제가 없는 것으로 확인된 아동이었다. 두 집단의 생활연령(월 령), 수용어휘 원점수, 자음정확도에 대한 정보는 Table 1과 같다. 두 집단 간 생활연령(월령)과 수용어휘 원점수에는 유의한 차이가
Table 1. Participants' characteristics in pure SSD and TD groups

\begin{tabular}{lcc}
\hline & Pure SSD (N=20) & TD (N=20) \\
\hline Chronological age (mo) & $62.05(7.92)$ & $60.55(7.61)$ \\
Vocabulary age (mo) & & \\
REVT-Receptive & $50.5(18.68)$ & $62.5(12.85)$ \\
U-TAP PCC (\%) & $76.18(2.10)$ & $98.36(2.51)$ \\
\hline
\end{tabular}

Values are presented as mean (SD).

pure SSD = children with pure speech sound disorders; TD = typically developing children; REVT = Receptive \& Expressive Vocabulary Test (Kim, Hong, Kim, Jang, \& Lee, 2009); U-TAP=Urimal Test of Articulation and Phonology (Kim \& Shin, 2004); PCC= percentage of consonants correct.

없었고 $(p>.05)$, 자음정확도만 순수 말소리장애 집단이 일반아동 집단보다 유의하게 낮았다 $(p<.001)$.

\section{실험 어휘 선정}

본 연구에서는 아동용 한국판 보스턴이름대기검사(Korean version-Boston Naming Test for children, K-BNT-C; Kim \& Na, 2007) 의 단어들을 실험 어휘로 이용하였다. 연구질문 1-3에 대해서는 KBNT-C의 60 개의 단어를 모두 이용하였다. 네 번째 연구질문인 두 집단 간 단어빈도에 따른 어휘인출 수행력을 비교하기 위해, Kang과 $\mathrm{Kim}$ (2009)을 참고하여 K-BNT-C의 60개 단어를 빈도 100 이상은 고빈도 단어로, 100 이하는 저빈도 단어로 정의하였다. 그 결과 고 빈도 단어는 21개, 저빈도 단어는 39개로 분류되었다(Appendix 1). 다섯 번째 연구질문인 두 집단 간 조음복잡성에 따른 어휘인출 수 행력을 비교하기 위해, Lee, Han과 Sim (2004)의 조음복잡성 지표 를 참고하여(Appendix 2) K-BNT-C의 60개 단어에 대해 조음복잡 성을 계산하였다. 조음복잡성 지표 1점에서 4점에 해당하는 단어 는 조음복잡성 '저' 단어로, 6점에서 9점은 조음복잡성 '고' 단어로 분류하였다. 조음복잡성 ‘저'와 '고' 단어 목록의 경계를 보다 명확 하게 하기 위해 조음복잡성 지표 5 점에 해당하는 단어는 실험 어휘 에서 제외하였다. 따라서 조음복잡성 '저' 단어는 24 개, 조음복잡 성 '고' 단어는 23 개로, 총 47 개 단어만이 다섯 번째 연구질문의 실 험 어휘로 사용되었다(Appendix 3).

고빈도와 저빈도 단어 세트의 목록 간 조음복잡성을 살펴본 결 과, 고빈도 단어는 평균 4.57 (1.96), 저빈도 단어는 평균 5.15 (1.89) 로, 빈도에 따른 두 어휘 세트 간 조음복잡성에는 유의한 차이가 없 었다 $(t=-1.032, p>$.05). 조음복잡성 '고'와 조음복잡성 '저' 단어 세 트의 목록 간 단어빈도를 살펴본 결과, 조음복잡성 '고' 단어는 평 균 127.06 (226.18), 조음복잡성 '저’ 단어는 평균 977.73 (2,774.99) 로, 조음복잡성에 따른 두 어휘 세트 간 단어빈도에는 유의한 차이 가 없었다 $(t=-1.180, p>.05)$. 


\section{연구절차}

실험 장소는 아동에게 낯설지 않는 곳(집 또는 어린이집)으로, 조 용한 공간에서 연구자와 일대일로 마주 앉아 진행하였다. K-BNT$\mathrm{C}$ 의 그림들을 하나씩 제시하면서 아동에게 "이 그림의 이름을 말 해주세요."라고 지시하였다. 본 과제를 실시하기 전 연습 과제를 충 분히 실시하여 아동으로 하여금 과제절차를 명확하게 이해하도록 하였다. 아동이 그림 이름 말하는 것을 어려워하여도 검사자는 아 무런 단서를 제공하지 않았다. 전체 실험은 약 20 분 소요되었다.

\section{자료처리}

실험과제로 K-BNT-C를 사용하였지만, 본 연구에서 보고자 하 는 대상자들의 어휘인출 수행력은 K-BNT-C의 점수와 동일한 것 은 아니다. 서론에서 언급하였듯이 대상자들이 머릿속에서 선택한 첫 어휘에 최대한 근접한 반응을 점수화하기 위해, Dell 등(1997)의 지침에 따라 그림자극에 대해 아무런 단서 없이 산출한 아동의 최 초 반응을 점수화하였다. 즉, 아동 스스로 산출한 첫 반응만 점수 화되었으며, 이에 대해 정반응은 1 점, 오반응은 0 점으로 처리하였 다. 채점 방법에 대해 유의하여 할 점은 다음과 같다. 첫째, 아동이 틀린 이름을 말한 후 즉각적으로 자가수정하여 올바른 이름을 산 출하였더라도, 아동의 첫 반응만이 점수화되기 때문에 이는 0 점으 로 처리된다. 둘째, 정반응 여부를 판단할 때 아동의 말소리산출 능 력을 고려한다. 예를 들어 파찰음을 파열음화시키는 아동이 파찰 음이 포함된 항목에 대해 파열음으로 일관되게 오조음하여 어휘 이름을 말한 경우, 이는 정반응으로 간주한다. 그러나 파찰음 조음 이 가능한 아동이 파찰음이 포함된 단어를 파열음으로 오조음하 여 그 이름을 말한 경우(예: '유모차' $\rightarrow[$ 유모카]), 이는 오반응으로 채점되고 오류유형은 ‘비단어’ 오류로 분류된다.

첫 번째 연구질문인 어휘인출과제의 총 점수는 이와 같은 채점 기 준을 적용한 대상자의 정반응 점수 총점을 의미한다. 두 번째와 세 번째 연구질문을 위한 오류유형 분석은 Dell 등(1997)의 기준에 근 거하였다. 구체적으로 살펴보면, 의미오류(semantic error)는 목표 어와 의미적으로 비슷한 단어를 선택한 경우, 형태오류(formal error)는 목표어와 음운적으로 비슷한 단어를 선택한 경우, 혼합오류 (mixed error)는 목표어와 의미 및 음운적으로 비슷한 단어를 선택 한 경우, 비관련 오류(unrelated error)는 목표 단어와 의미 및 음운 적으로 관련 없는 단어를 선택한 경우, 비단어 오류(nonword error) 는 우리말에서 단어로 존재하지 않는 말소리 조합을 산출하는 경우 이다. 아동이 그림을 보고 첫 반응으로 “몰라요”라고 대답한 경우 에는 선행연구에 근거하여 어휘오류(lexical error)에 해당되지 않으 므로 오류분석에서 제외시켰다. 모든 오류유형은 분석하기 앞서 사
전을 통해 다시 한 번 확인하고 분류하였다. 이와 같은 기준을 우리 말에 적용할 때 유의할 점 등은 $\mathrm{Ha}$ 와 $\operatorname{Sim}$ (2011a)의 연구를 참고하 였다. 두 번째 연구질문을 위한 오류유형 비율은 대상자의 전체 오 류수에 대한 각 오류유형수의 비율을 구한 후, 이에 대해 100 을 곱 하여 백분율로 계산하였다. 세 번째 연구질문을 위해서는 K-BNTC 60개 항목에 대한 대상자의 정반응 개수와각 오류유형별 개수를 WebFit 프로그램에 직접 입력하여 그 결과를 얻었다. WebFit 프로 그램은 해당 웹사이트(http://langprod.cogsci.uiuc.edu/cgi-bin/ webfit.cgi)에서 무료로 손쉽게 이용할 수 있다. 네 번째와 다섯 번째 연구질문에 대해서는 어휘 세트 간 항목 수가 동일하지 않았기 때 문에, 각 세트에 대한 정반응 점수를 백점 만점으로 환산하였다.

\section{통계 분석}

통계 분석은 SPSS version 22.0 (IBM, Armonk, NY, USA)을 이 용하여 분석하였다. 첫 번째 연구질문인 두 집단 간 어휘인출 수행 력에 차이가 있는지 확인하기 위해, 독립표본 $t$-검정을 실시하였다. 두 번째, 네 번째, 다섯 번째 연구질문인 오류유형, 단어빈도, 조음 복잡성에 따른 두 집단 간 수행력 차이를 알아보기 위해, 1 피험자 간-1 피험자 내 혼합설계에 의한 반복측정 분산분석(Repeated Measure ANOVA)을 실시하였다. 구형성 가정이 성립되지 않은 경우 Greenhouse-Geisser 자유도를 이용한 조정값으로 결과를 해석하 였고, 주효과 검정은 Bonferroni 사후검정을, 상호작용효과 검정은 COMPARE syntax를 입력하여 분석하였다. 세 번째 연구질문인 두 집단 간 S-L 손상과 L-P 손상의 분포를 비교하기 위해서는, 두 집단 간 피셔 검정(Fisher's exact test)을 실시하였다.

\section{연구결과}

\section{두 집단 간 어휘인출과제 총 점수 비교}

K-BNT-C 전체 항목에 대해 순수 말소리장애 아동과 일반아동 의 어휘인출과제 총 점수를 측정하였다. 그 결과 일반아동은 평균 62.25점(11.45), 순수 말소리장애 아동은 평균 56.75점(17.35)으로 일반아동의 정반응 점수가 평균적으로 높았다. 독립표본 $t$-검정 결 과 두 집단 간차이는 통계적으로 유의하였다 $(t=4.168, p<.001)$.

\section{두 집단 간 오류유형별 오류율 비교}

순수 말소리장애 아동과 일반아동 간 각 오류유형의 비율에 대 한 기술통계는 Table 2 와 같다. 일반아동의 경우 평균 의미 오류율 $83.47 \%$ (5.73), 형태 오류율 .55\% (1.74), 혼합 오류율 4.56\% (1.65), 비관련 오류율 7.36\% (3.10), 비단어 오류율 $4.06 \%$ (5.16)로, 의미 오 
Table 2. Percentage (\%) of error types in two groups

\begin{tabular}{lrr}
\hline & TD $(\mathrm{N}=20)$ & pure SSD $(\mathrm{N}=20)$ \\
\hline Semantic error & $83.47(5.73)$ & $46.35(5.73)$ \\
Formal error & $.55(1.74)$ & $5.63(1.74)$ \\
Mixed error & $4.56(1.65)$ & $1.80(1.65)$ \\
Unrelated error & $7.36(3.10)$ & $11.30(3.10)$ \\
Nonword & $4.06(5.16)$ & $34.92(5.16)$ \\
\hline
\end{tabular}

Values are presented as mean (SD).

$\mathrm{TD}=$ typically developing children; pure $\mathrm{SSD}=$ children with pure speech sound disorders.

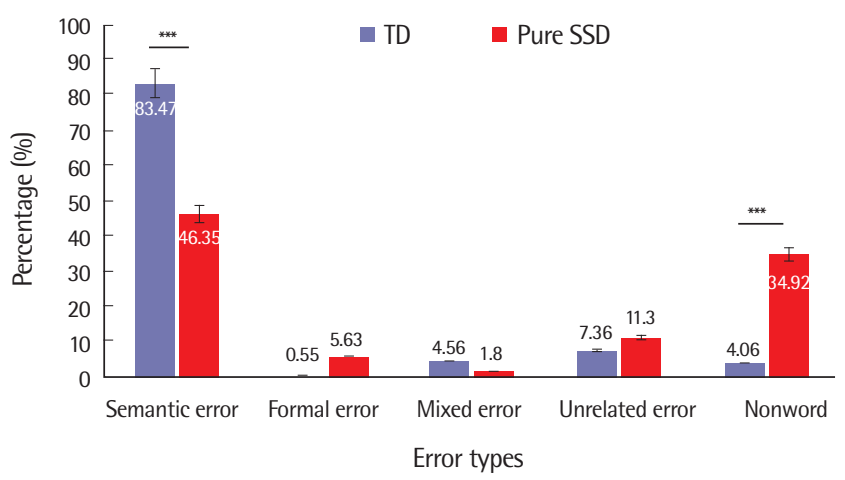

Figure 1. Percentage (\%) of error types of lexical retrieval task in two groups. $\mathrm{TD}=$ typically developing children; pure SSD = children with pure speech sound disorders. ${ }^{* * *} p<.001$.

류율이 가장 높았다. 순수 말소리장애 아동의 평균 의미 오류율은 $46.35 \%$ (5.73), 형태 오류율은 5.63\% (1.74), 혼합 오류율은 $1.80 \%$ (1.65), 비관련 오류율은 $11.30 \%$ (3.10), 비단어 오류율은 $34.92 \%$ (5.16)였다. 일반아동과 마찬가지로 의미 오류율이 가장 두드러졌 만, 비단어 오류율 또한 의미 오류율만큼 높아진 것이 관찰되었다.

혼합설계에 따른 반복측정 분산분석 결과 집단 간 주효과는 유 의하지 않았으나 $\left(F_{(1,38)}=.036, p>.05\right)$, 이는 오류유형의 백분율로 두 집단을 비교하였기 때문에 나타난 당연한 결과이다. 집단 내 오 류유형에 따른 주효과 $\left(F_{(1,38)}=72.279, p<.001\right)$, 그리고 집단과 오류 유형 간 상호작용효과가 유의하였다 $\left(F_{(1.8,70.60)}=15.925, p<.001\right)$. 오 류유형의 주효과에 대해 Bonferroni 사후검정을 실시한 결과, 의미 오류율은 다른 모든 오류율보다 유의하게 높았고( $p<.001)$, 비단어 오류율은 형태 오류율과 혼합 오류율보다 유의하게 높았다( $p<.001)$ 집단과 오류유형 간 상호작용효과에 대해 COMPARE syntax를 입 력하여 분석한 결과, 의미 오류와 비단어 오류에서 두 집단 간 차이 가 유의한 것으로 확인되었다( $p<.001)$. 그러나 두 오류유형 간 반 대 양상을 보였는데, 의미 오류율은 일반아동에서, 비단어 오류율 은 순수 말소리장애 아동에서 유의하게 높게 나타났다(Figure 1).
Table 3. Scores according to word frequency in two groups

\begin{tabular}{llc}
\hline & TD $(\mathrm{N}=20)$ & pure SSD $(\mathrm{N}=20)$ \\
\hline Words of high frequency & $79.76(10.35)$ & $63.09(11.75)$ \\
Words of low frequency & $33.46(11.58)$ & $19.81(7.41)$
\end{tabular}

Values are presented as mean (SD).

$\mathrm{TD}=$ typically developing children; pure SSD = children with pure speech sound disorders.

Table 4. Scores according to phonetic complexity in two groups

\begin{tabular}{lll}
\hline & TD (N=20) & pure SSD (N=20) \\
\hline Phonetic complexity 'high' & $38.13(7.44)$ & $32.71(5.94)$ \\
phonetic complexity 'low' & $79.76(10.35)$ & $63.09(11.75)$ \\
\hline
\end{tabular}

Values are presented as mean (SD).

$\mathrm{TD}=$ typically developing children; pure SSD = children with pure speech sound disorders.

\section{두 집단 간 WebFit 프로그램 실시 결과}

두 집단이 어휘인출과제 수행 중 보인 오류들을 WebFit 프로그 램으로 분석하였다. 그 결과 일반아동의 경우 20 명 중 17 명이 S-L 손상에, 3명이 L-P 손상에 해당하였고, 순수 말소리장애아동의 경 우 20명 중 14명이 S-L 손상에, 6명이 L-P 손상에 해당하였다. 이에 대해 피셔 검정(Fisher's exact test)을 실시한 결과, 두 집단 간 S-L 손 상과 L-P 손상의 분포에는 유의한 차이가 없었다 $(F=.262, p>.05)$.

\section{두 집단 간 단어 빈도에 따른 수행력 비교}

순수 말소리장애 아동과 일반아동 간 단어빈도(고빈도, 저빈도) 에 따른 수행력에 대한 기술통계는 Table 3과 같다. 일반아동의 고 빈도 어휘 평균 점수는 79.76점(10.35), 저빈도 어휘 평균 점수는 33.46점(11.58)이었고, 순수 말소리장애 아동의 고빈도 어휘 평균 점수는 63.09점(11.75), 저빈도 어휘 평균 점수는 19.81점(7.41)이었다.

혼합설계에 따른 반복측정 분산분석을 실시한 결과, 집단 간 주 효과 $\left(F_{(1,18)}=26.341, p<.001\right)$, 그리고 집단 내 단어빈도에 따른 주 효과가 유의하였으나 $\left(F_{(1,18)}=940.821, p<.001\right)$, 집단과 단어빈도에 따른 상호작용효과는 유의하지 않았다 $\left(F_{(1,18)}=1.604, p>.05\right)$. 즉, 단어빈도에 상관없이 순수 말소리장애 집단은 일반아동보다, 그리 고 집단에 상관없이 저빈도 단어는 고빈도 단어에서보다 어휘인출 수행력이 떨어졌다.

\section{두 집단 간 조음복잡성에 따른 수행력 비교}

순수 말소리장애 아동과 일반아동 간 조음복잡성(고, 저)에 따 른 수행력에 대한 기술통계는 Table 4와 같다. 일반아동은 조음복 잡성 '고' 어휘에서 평균 38.13점(7.44), 조음복잡성 '저' 어휘에서 평 


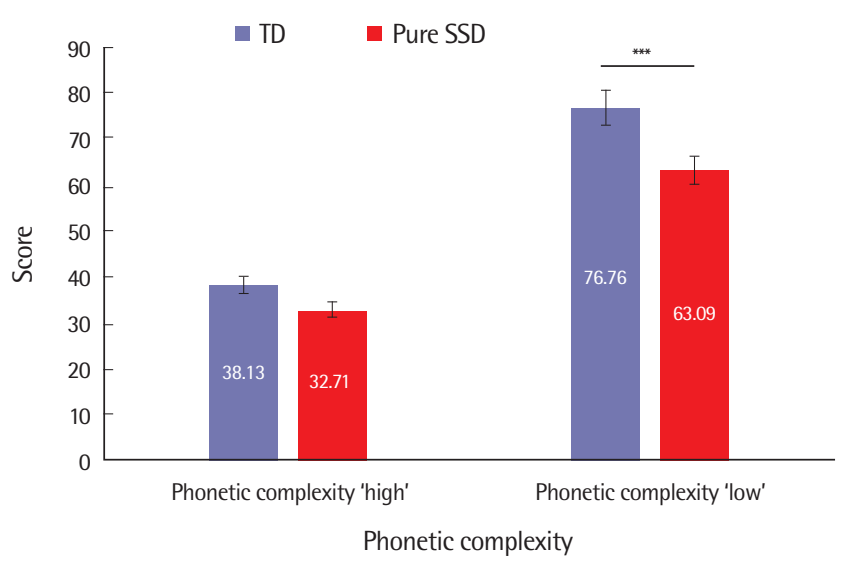

Figure 2. Lexical retrieval scores of phonetic complexity 'high' and 'low' words in two groups.

$\mathrm{TD}=$ typically developing children; pure SSD = children with pure speech sound disorders. ${ }^{* * *} p<.001$.

균 79.76점(10.35)을, 순수 말소리장애 아동은 조음복잡성 '고' 어휘 에서 평균 32.71점(5.94), 조음복잡성 '저' 어휘에서 평균 63.09점 (11.75)을 보였다.

혼합설계에 따른 반복측정 분산분석 결과, 집단 간 $\left(F_{(1,38)}=19.513\right.$, $p<.001)$, 집단 내조음복잡성에 따른주효과 $\left(F_{(1,38)}=717.064, p<.001\right)$, 그리고 집단과 조음복잡성에 따른 상호작용효과가 모두 유의하였 다 $\left(F_{(1,38)}=17.508, p<.001\right)$. 즉, 조음복잡성 정도에 상관없이 순수 말소리장애 아동은 일반아동보다, 그리고 집단에 상관없이 조음 복잡성 '고' 어휘는 조음복잡성 '저' 어휘에서보다 어휘인출 수행력 이 떨어졌다. 집단과 조음복잡성의 상호작용효과를 분석하기 위해 COMPARE syntax를 입력하여 사후검정을 실시한 결과, 조음복잡 성 '저'에서만 두 집단 간 차이가 유의한 것이 확인되었다 $(p<.001)$ (Figure 2).

\section{논의 및 결론}

본 연구에서는 순수 말소리장애 아동과 일반아동 간 어휘인출 수행력과 과제 수행 시 나타난 오류의 양상을 비교하고, 단어빈도 와 조음복잡성이 두 집단의 어휘인출 수행에 미치는 영향에 대해 알아보았다. 그 결과 순수 말소리장애 아동은 일반아동보다 어휘 인출과제의 총점이 유의하게 낮았고, 비단어 오류를 유의하게 많 이 보였다. SP 모델에 근거를 둔 WebFit 프로그램을 적용했을 때 일 반 집단보다 순수 말소리장애 집단에서 L-P 집단으로 분류된 아동 이 많았으나, 그 차이가 통계적으로 유의하지는 않았다. 단어빈도 와 조음복잡성은 두 집단 모두에서 어휘인출 수행에 영향을 주었 는데, 조음복잡성 '고' 어휘의 경우 일반아동도 매우 어려워하여 두
집단 간 차이가 유의하지 않았다. 이와 같은 연구결과 각각에 대해 보다 심층적인 논의가 필요할 것이다.

첫째, 순수 말소리장애 아동이 일반아동보다 어휘인출과제의 총 점이 유의하게 낮았다는 연구결과는 말소리산출에만 어려움을 보 일 뿐 다른 결함은 없는 것으로 간주되었던 순수 말소리장애에 대 해 다소 다른 관점을 제시한다. 말소리장애 아동에서 언어장애를 동반한 경우는 그렇지 않은 경우보다 유의하게 많다는 것은 이미 잘 알려져 있다(Kim \& Shin, 2015; Macrae, Tyler, \& Lewis, 2014). 또한 연구자는 실험 시작 전 표준화 어휘검사를 통해 대상자들이 일반아동과 어휘량에 차이가 없음을 확인하였다. 그럼에도 불구하 고 어휘인출과제의 수행력이 떨어졌다는 연구결과는 보다 심층적 평가 또는 분석을 실시할 때에야 비로소 아동들의 결함이 드러날 가능성을 시사한다. 심층적 평가에는 여러 방법이 있겠지만, 본 연 구와 같이 기존 과제에 대해 처리과정에 좀 더 초점을 둔 분석 절차 를 적용해 볼 수도 있다. 그 이유는 정적 지식보다 역동적 처리능력 을 평가할 때에 비로소 기저의 취약점이 드러날 수 있기 때문이다. 따라서 진단가는 평가 또는 분석 방법 등의 제한으로 인해 대상자 의 결함이 드러나지 않았을 가능성을 항상 염두에 두고, 대상자의 전 의사소통능력을 보다 명확하게 파악하기 위해 부단히 노력해야 할 것이다.

순수 말소리장애 아동이 어휘인출과정 중 어떤 어려움을 겪었는 지에 대한 답은 두 번째 연구질문의 결과에서 얻을 수 있다. 어휘인 출과제 수행 시 나타난 오류는 일반아동의 경우 의미 오류가 $83.47 \%$ 로, 오류의 대부분을 차지하였다(Table 2). 반면 순수 말소리장애 아동의 경우 의미 오류율이 $46.35 \%$ 로 일반아동에 비해 그 비율이 매우 적었고, 대신 비단어 오류를 $34.92 \%$ 보여 일반아동의 비단어 오류율인 $4.06 \%$ 보다 8 배 이상 높았다(Table 2). 비단어 오류는 어 휘후 단계(sublexical stage), 즉 어휘선택 후 어휘소(음운표상) 또는 음운부호화(phonological encoding) 과정에서 발생하는 오류이며 (Ha \& Sim, 2011a), 때문에 이는 말소리장애라는 대상자의 특성이 반영된 것으로 보인다. 채점 시 대상자의 조음능력을 반영하여 조 음문제로 인한 오류는 모두 정반응으로 처리했음에도 불구하고, 이처럼 비단어 오류가 많이 나타난 것은 대상자들의 취약한 음운 처리능력을 시사한다. 장기기억에 저장된 어휘는 의미뿐 아니라 음 운형태를 갖추고 있는 언어지식이라는 점을 상기할 때, 음운처리에 결함이 있는 말소리장애 아동이 어휘의 음운형태에 접근하고, 그 것을 인출, 기억, 부호화하는 과정에 어려움을 겪고 그 결과 어휘인 출 오류를 보이게 되는 것은 어쩌면 당연한 것으로 여겨진다.

그러나 말소리장애 아동은, 그 비율이 일반아동보다 훨씬 적긴 했지만, 비단어 오류보다도 의미 오류를 더 많이 보였다. 세 번째 연 
구질문인 WebFit 프로그램에 의한 S-L 집단과 L-P 집단의 분류에 서도 순수 말소리장애 집단에서 L-P 집단으로 분류된 아동수가 일 반 집단보다 더 많긴 했지만, 일반 집단과 마찬가지로 S-L 집단으로 분류된 아동이 가장 많았다. 다시 말해 말소리장애 아동은 어휘음운 간 연결망이 약하고, 따라서 음운처리 결함과 관련된 오류를 더 많이 보이긴 하였지만, 그보다도 의미와 어휘 간 연결에 더욱 빈 번하게 방해를 받았고 이는 의미와 관련된 오류들로 연결되었다. 이는 일반아동, 정상 성인, 실어증 환자 등 대상자에 상관없이 공통 적으로 나타나는 언어 현상이기도 하다(Ahn, 2016; Dell et al., 1997;

Ha \& Sim, 2011a). Nooteboom과 Quene (2008)은 이러한 현상을 오류의 어휘편향화(lexical bias)라고 하였다. 말은 그것을 산출하기 직전 내적으로 모니터링을 하는 과정을 거치게 된다. 이때 산출하 고자 하는 말이 머릿속에 저장되어 있지 않은 형태, 즉 비단어 형태 로 잘못 형성되었을 경우 그 오류는 모니터링 과정에서 쉽게 감지되 어, 다시 내적으로 수정하는 절차를 거치게 된다. 따라서 최종적으 로 비단어 오류를 산출하는 경우는 드물다. 반면 오류가 머릿속에 저장되어 있는 단어일 경우 그 오류는 내적으로 쉽게 감지되지 않 기 때문에, 수정 절차를 거치지 못한 채 입 밖으로 산출하게 된다. 때문에 대부분의 오류는 그 나라 언어에 존재하는 어휘의 형태로 이루어져 있다(Nooteboom \& Quene, 2008). 이러한 오류의 어휘편 향화 이론에 근거하여, 말소리장애 아동과 일반아동 모두 단어로 이루어진 의미 오류가 가장 많이 보였다는 본 연구결과에 대해 타 당한 해석이 가능할 것이다. 그럼에도 불구하고 순수 말소리장애 아동에서 비단어 오류율이 상당히 높았다는 연구결과는 말소리장 애 아동의 모니터링 능력의 결함 등에 대해 시사하는 바가 있으며, 이에 대해서는 추후 후속연구가 필요할 것이다.

네 번째 연구질문인 어휘인출에 대한 단어빈도의 영향은 선행연 구들의 결과와 다르지 않았다(Dell, 1990; Jeong, Choi, \& Hwang, 2014; Jeschneiak \& Levelt, 1994; Navarrete, Basagni, Alario, \& Costa, 2006; Storkel \& Morrisette, 2002). 즉, 저빈도 어휘를 인출하는 것은 고빈도 어휘를 인출하는 것보다 부담이 되는 일이며, 이것은 말소리장애 아동과 일반아동 모두에게 해당되었다. 그보다 다섯 번째 연구질문인 어휘인출에 대한 조음복잡성의 영향에서 예상하 지 못했던 흥미로운 결과가 관찰되었다. 두 집단 모두 조음복잡성 이 낮은 어휘보다 높은 어휘에서 어휘인출 수행력이 유의하게 떨어 졌다. 이는 구어산출과정에서 조음부의 이전 단계로의 역방향적 영향을 시사하며, 따라서 구어산출의 각 단계 간 쌍방향적 상호작 용을 지지하는 결과이다. 그뿐만 아니라 조음복잡성이 높은 어휘 의 경우 일반아동도 그 수행력이 매우 떨어져 순수 말소리장애 아 동과 집단적으로 차이가 나타나지 않았다. 일반아동의 오류 대부
분이 의미 오류였음을 상기할 때, 조음복잡성이 높을 경우 일반아 동은 어휘인출과정에서 큰 방해를 받았고 그 결과 의미적으로 유 사한 다른 어휘를 잘못 선택하는 오류가 빈번하게 발생했다는 해석 이 가능하다. 이는 조음부가 의미표제어 선택 단계, 즉 비인접 단계 에 역방향적으로 영향을 미치고 있음을 시사하는 것이다. 이러한 연구결과는 구어산출과정의 각 단계는 활발하게 상호작용하고 있 고, 그 관계는 일방적이 아닌 쌍방향적임을 명백히 보여주고 있다.

이상과 같이 살펴보았듯이 본 연구는 순수 말소리장애 아동의 어휘인출능력에 대해 심층적 분석을 실시하여 언어장애로 진단받 지 않았지만 그들의 언어능력이 결코 안전하지 않을 가능성을 제안 하였다는 점에서 의미가 있다. 또한 연구결과가 일관되게 제시하고 있는 구어산출과정의 각 단계 간 상호 영향은 의사소통장애 아동 의 전 의사소통 영역에 대한 심층적 평가와 진단의 중요함을 강조 한다. 이는 오래 전 의사소통장애 아동의 언어 하위영역 간 상호작 용효과에 대해 주장하였던 Crystal (1987)의 'bucket theory'와도 맥락을 같이한다. 따라서 임상가는 의사소통장애 아동의 한 언어 영역에서의 일차적인 문제의 발견이 진단의 끝이 아니라 출발점일 뿐임(Crystal, 1987)을 항상 명심하여야 할 것이다.

\section{REFERENCES}

Ahn, J. A. (2016). Performance of receptive lexical selection test (LST) in preschoolers with and without speech sound disorders (Master's thesis). Daegu University, Gyeongsan, Korea.

Budd, M. J., Hanley, J. R., \& Griffiths, Y. (2011). Simulating children's retrieval errors in picture-naming: a test of Foygel and Dell's (2000) semantic/phonological model of speech production. Journal of Memory and Language, 64, 74-87.

Crystal, D. (1987). Towards a 'bucket' theory of language disability: taking account of interaction between linguistic levels. Clinical Linguistics and Phonetics, 1, 7-22.

Dell, G. S. (1986). A spreading-activation theory of retrieval in sentence production. Psychological Review, 93, 283-321.

Dell, G. S. (1990). Effects of frequency and vocabulary type on phonological speech error data. Language and Cognitive processes, 5, 313-349.

Dell, G. S., Schwartz, M. F., Martin, N., Saffran, E. M., \& Gagnon, D. A. (1997). Lexical access in aphasic and nonaphasic speakers. Psychological Review, 104, 801-838.

Fink, A., Oppenheim, G. M., \& Goldrick, M. (2017). Interactions between lexical access and articulation. Language, Cognition and Neuroscience, 33, 
$12-24$.

Foygel, D., \& Dell, G. S. (2000). Models of impaired lexical access in speech production. Journal of Memory and Language, 43, 182-216.

Goldrick, M., McClain, R., Cibelli, E., Adi, Y., Gustafson, E., Moers, C., \& Keshet, J. (2018). The influence of lexical selection disruptions on articulation. Journal of Experimental Psychology. Learning, Memory, and Cognition. Advanced online publication. DOI: 10.1037/xlm0000633.

Heisler, L., Goffman, L., \& Younger, B. (2010). Lexical and articulatory interactions in children's language production. Developmental Science, 13, 722730.

Ha, J. W., \& Sim, H. S. (2011a). Application of WebFit for diagnosis of lexical disorders in Korean aphasia. Korean Journal of Communication \& Disorders, 16, 231-247.

Ha, J. W., \& Sim, H. S. (2011b). The relationship between lexical retrieval and coverbal gestures. Cognition Science, 22, 123-143.

Jeong, H. W., Choi, S. Y., \& Hwang, M. A. (2014). Word frequency and length effects on the lexical decisions of adults with anomic aphasia. Communication Sciences \& Disorders, 19, 80-88.

Jescheniak, J. D., \& Levelt, W. J. M. (1994). Word frequency effects in speech production: retrieval of syntactic information and of phonological form. Journal of Experimental Psychology: Learning, Memory, and Cognition, 20, 824-843.

Kang, B. M., \& Kim, H. G. (2009). Frequency of usage of Korean. Seoul: Hankook munhwasa.

Kim, H. H., \& Na, D. L. (2007). Korean version-Boston Naming Test for children (K-BNT-C). Seoul: Hakjisa.

Kim, N. Y., \& Ha, J. W. (2014). Phonological representations in children with articulation and phonological disorders. Communication Sciences \& Disorders, 19, 226-237.

Kim, S. J., \& Shin, J. Y. (2015). Speech sound disorders. Seoul: SigmaPress.

Kim, Y. T., Hong, G. H., Kim, K. H., Jang, H. S., \& Lee, J. Y. (2009). Receptive and expressive vocabulary test (REVT). Seoul: Seoul Community Rehabilitation Center.

Kim, Y. T., \& Shin, M. J. (2004). Urimal Test of Articulation and Phonology (U-TAP). Seoul: Hakjisa.

Lee, E. J., Han, J. S., \& Sim, H. S. (2004). Effects of the phonetic complexity on the disfluencies and the articulation errors of people who stutter. Korean Journal of Communication \& Disorders, 9, 139-156.

Levelt, W. J. M. (1991). Lexical access in speech production. Cambridge, MA: Blackwell.

Levelt, W. J. M., Roelofs, A., \& Meyer, A. S. (1999). A theory of lexical access in speech production. Behavioral and Brain Sciences, 22, 1-38.

Macrae, T., Tyler, A, A., \& Lewis, K. E. (2014). Lexical and phonological variability in preschool children with speech sound disorder. American Journal of Speech-Language Pathology, 23, 27-35.

Navarrete, E., Basagni, B., Alario, F. X., \& Costa, A. (2006). Does word frequency affect lexical selection in speech production? Journal of Experimental Psychology, 59, 1681-1690.

Nooteboom, S., \& Quene, H. (2008). Self-monitoring and feedback: a new attempt to find the main cause of lexical bias in phonological speech errors. Journal of Memory and Language, 58, 837-861.

Storkel, H, L., \& Morrisette, M, L. (2002). The lexicon and phonology: interactions in language acquisition. Language, Speech, and Hearing Services in Schools, 33, 24-37. 
Appendix 1. The list of words according to the word frequency

\begin{tabular}{|c|c|c|c|c|c|c|c|}
\hline \multicolumn{4}{|c|}{ 고빈도 단어 목록 } & \multicolumn{4}{|c|}{ 저빈도 단어 목록 } \\
\hline & 단어 & 빈도 & 조음복잡성 & & 단어 & 빈도 & 조음복잡성 \\
\hline 1 & 손 & 11,796 & 2 & 1 & 도토리 & 86 & 2 \\
\hline 2 & 용 & 4,087 & 3 & 2 & 선인장 & 82 & 8 \\
\hline 3 & 자전거 & 915 & 8 & 3 & 눈사람 & 81 & 5 \\
\hline 4 & 모자 & 622 & 2 & 4 & 등대 & 77 & 3 \\
\hline 5 & 고추 & 574 & 2 & 5 & 저울 & 75 & 3 \\
\hline 6 & 넥타이 & 274 & 5 & 6 & 바둑판 & 72 & 5 \\
\hline 7 & 풍선 & 263 & 5 & 7 & 지네 & 72 & 2 \\
\hline 8 & 태극기 & 247 & 5 & 8 & 야자수(나무) & 62 & 5 \\
\hline 9 & 공룡 & 213 & 7 & 9 & 소화기 & 59 & 5 \\
\hline 10 & 바나나 & 169 & 1 & 10 & 하모니카 & 58 & 3 \\
\hline 11 & 거미줄 & 160 & 6 & 11 & 가재 & 40 & 3 \\
\hline 12 & 낙타 & 147 & 3 & 12 & 나침반 & 40 & 5 \\
\hline 13 & 수갑 & 146 & 3 & 13 & 올챙이 & 39 & 9 \\
\hline 14 & 버섯 & 139 & 2 & 14 & 유모차 & 38 & 4 \\
\hline 15 & 달팽이 & 134 & 7 & 15 & 거북선 & 35 & 7 \\
\hline 16 & 신호등 & 124 & 6 & 16 & 에스컬레이터 & 35 & 6 \\
\hline 17 & 선풍기 & 108 & 6 & 17 & 청진기 & 27 & 11 \\
\hline 18 & 장화 & 108 & 7 & 18 & 인어공주 & 25 & 7 \\
\hline 19 & 박쥐 & 105 & 6 & 19 & 고드름 & 24 & 4 \\
\hline 20 & 현미경 & 102 & 9 & 20 & 불가사리 & 20 & 7 \\
\hline 21 & 장구 & 101 & 5 & 21 & 첨성대 & 18 & 9 \\
\hline 22 & & & & 22 & 깔때기 & 16 & 4 \\
\hline 23 & & & & 23 & 지구본 & 9 & 5 \\
\hline 24 & & & & 24 & 모래시계 & 3 & 6 \\
\hline 25 & & & & 25 & 돌하루방 & 3 & 7 \\
\hline 26 & & & & 26 & 도르래 & 11 & 3 \\
\hline 27 & & & & 27 & 목발 & 73 & 5 \\
\hline 28 & & & & 28 & 토시 & 18 & 2 \\
\hline 39 & & & & 29 & 석류 & 60 & 5 \\
\hline \multirow[t]{11}{*}{30} & & & & 30 & 골무 & 10 & 4 \\
\hline & & & & 31 & 작살 & 7 & 8 \\
\hline & & & & 32 & 방독면 & 40 & 9 \\
\hline & & & & 33 & 대패 & 1 & 1 \\
\hline & & & & 34 & 평행봉 & 6 & 11 \\
\hline & & & & 35 & 고깔 & 22 & 4 \\
\hline & & & & 36 & 풍경 & 24 & 6 \\
\hline & & & & 37 & 소코뚜레 & 1 & 4 \\
\hline & & & & 38 & 흙손 & 3 & 5 \\
\hline & & & & 39 & 뗏목 & 1 & 5 \\
\hline & 평균 & 977.81 & 4.76 & & 평균 & 35.21 & 5.26 \\
\hline
\end{tabular}


Appendix 2. Korean index of phonetic complexity scoring schema

\begin{tabular}{lcc}
\hline 개별 지표 & 점 & 1점 \\
\hline 1. 자음의 조음위치 & 양순음, 치경음, 성문음 & 치경경구개음, 연구개음 \\
2. 자음의 조음방법 & 폐쇄음, 비음 & 마찰음, 파찰음, 유음 \\
3. 모음의 종류 & 단모음 & 이중모음 \\
4. 음절의 형태 & 모음으로 끝남(개방형) & 자음으로 끝남(폐쇄형) \\
5. 어절의 길이 & $1-2$ 음절 & 3음절 이상 \\
6. 인접자음의 출현여부 & 없음 & 있음 \\
7. 인접자음의 조음위치 & 같음 & 다름 \\
\hline
\end{tabular}

Appendix 3. The list of words according to the phonetic complexity

\begin{tabular}{|c|c|c|c|c|c|c|c|}
\hline \multicolumn{4}{|c|}{ 조음복잡성 ‘저’ 단어 목록 } & \multicolumn{4}{|c|}{ 조음복잡성 ‘고' 단어 목록 } \\
\hline & 단어 & 조음복잡성 & 빈도 & & 단어 & 조음복잡성 & 빈도 \\
\hline 1 & 대패 & 1 & 1 & 1 & 청진기 & 11 & 27 \\
\hline 2 & 깔때기 & 4 & 16 & 2 & 자전거 & 8 & 915 \\
\hline 3 & 소코뚜레 & 4 & 1 & 3 & 달팽이 & 7 & 134 \\
\hline 4 & 고깔 & 4 & 22 & 4 & 선풍기 & 6 & 108 \\
\hline 5 & 유모차 & 4 & 38 & 5 & 선인장 & 8 & 82 \\
\hline 6 & 고드름 & 4 & 24 & 6 & 돌하루방 & 7 & 3 \\
\hline 7 & 저울 & 3 & 75 & 7 & 공룡 & 7 & 213 \\
\hline 8 & 버섯 & 2 & 139 & 8 & 신호등 & 6 & 124 \\
\hline 9 & 고추 & 2 & 574 & 9 & 박쥐 & 6 & 105 \\
\hline 10 & 낙타 & 3 & 147 & 10 & 모래시계 & 6 & 3 \\
\hline 11 & 용 & 3 & 4,087 & 11 & 인어공주 & 7 & 25 \\
\hline 12 & 가재 & 3 & 40 & 12 & 장화 & 7 & 108 \\
\hline 13 & 하모니카 & 3 & 58 & 13 & 불가사리 & 7 & 20 \\
\hline 14 & 수갑 & 3 & 146 & 14 & 올챙이 & 9 & 39 \\
\hline 15 & 등대 & 3 & 77 & 15 & 거북선 & 7 & 35 \\
\hline 16 & 모자 & 2 & 622 & 16 & 현미경 & 9 & 102 \\
\hline 17 & 손 & 2 & 11,796 & 17 & 첨성대 & 9 & 18 \\
\hline 18 & 뗏목 & 5 & 1 & 18 & 거미줄 & 6 & 160 \\
\hline 19 & 도토리 & 2 & 86 & 19 & 풍경 & 6 & 24 \\
\hline 20 & 지네 & 2 & 72 & 20 & 방독면 & 9 & 40 \\
\hline 21 & 도르래 & 3 & 11 & 21 & 평행봉 & 11 & 6 \\
\hline 22 & 토시 & 2 & 18 & 22 & 작살 & 8 & 7 \\
\hline 23 & 골무 & 4 & 10 & 23 & 에스컬레이터 & 6 & 35 \\
\hline 24 & 바나나 & 1 & 169 & & & & \\
\hline & & 2.79 & 759.58 & & & 7.52 & 101.43 \\
\hline
\end{tabular}




\section{국문초록}

\section{순수 말소리장애 아동과 일반아동 간 단어빈도 및 조음복잡성에 따른 어휘인출능력 비교 김나연'(학생, 제1저자) · 하지완(교수, 교신저자) \\ ${ }^{1}$ 대구대학교 일반대학원 재활과학과 언어치료전공, ${ }^{2}$ 대구대학교 언어치료학과}

배경 및 목적: 본 연구는 순수 말소리장애 아동과 일반아동을 대상으로 어휘인출과제를 실시하여 두 집단 간 어휘인출능력을 비교하 고, 단어빈도와 조음복잡성이 대상자의 어휘인출 수행력에 미치는 영향을 알아보고자 하였다. 방법: 4-6세 순수 말소리장애 아동 20 명, 일반아동 20 명을 대상으로 하였다. 어휘인출 과제는 제시된 그림을 보고 즉각적으로 답하는 과제로, 대상자별로 개별적으로 진행되 었다. 어휘인출 점수와 오류유형별 비율을 측정하여 집단 간 비교하였고, 정반응수와 오류수를 WebFit 프로그램에 입력하여 대상자가 S-L 결함과 L-P 결함 중 어디에 해당하는지 분석하였다. 그리고 두 집단 간 단어빈도와 조음복잡성에 따른 어휘인출 과제 수행력을 비 교하였다. 결과: 순수 말소리장애 집단은 일반 집단보다 유의하게 낮은 어휘인출 수행력을 보였고, 비단어 오류를 유의하게 많이 보였 다. 순수 말소리장애 집단은 일반 집단보다 L-P 집단에 해당하는 아동이 더 많았지만, 그 차이는 통계적으로 유의하지 않았다. 두 집단 모두 단어빈도가 낮고 조음복잡성이 높은 어휘목록에서 수행력이 떨어졌다. 그러나 조음복잡성이 높은 경우 두 집단 간차이는 유의하 지 않았다. 논의 및 결론: 순수 말소리장애 아동의 불안정한 어휘인출능력, 그리고 조음능력과 어휘인출능력 간 관계에 대해 시사하고 있다.

핵심어: 말소리장애, 어휘인출, 단어빈도, 조음복잡성

본 논문은 2017년 정부(교육부)의 재원으로 한국연구재단의 지원을 받아 수행된 연구임(NRF-2017R1C1B1010913).

\section{참고문헌}

강범모, 김흥규(2009). 한국어 사용 빈도. 서울: 한국문화사

김나연, 하지완(2014). 조음음운장애아동과 일반아동의 음운표상의 질과 음운표상 부호화 능력 비교. Communication Sciences \& Disorders, 19,

226-237.

김수진, 신지영(2015). 말소리장애. 서울: 시그마프레스.

김영태, 신문자(2004). 우리말 조음·음운평가(U-TAP). 서울: 학지사.

김영태, 홍경훈, 김경희, 장혜성, 이주연(2009). 수용·표현어휘력검사(REVT). 서울: 서울장애인 종합복지관.

김향희, 나덕렬(2007). 아동용 한국판 보스톤 이름대기검사(K-BNT-C). 서울: 학지사.

안진아(2016). 학령전기 일반아동과 말소리장애 아동의 수용기반 어휘선택과제 수행력. 대구대학교 대학원 석사학위논문.

이은주, 한진순, 심현섭(2004). 조음복잡성이 비유창성과 조음오류에 미치는 영향. 언어청각장애연구, 9, 139-156.

정혜원, 최소영, 황민아(2014). 명칭 실어증 환자의 어휘 판단에서 단어 빈도 및 길이 효과. Communication Sciences \& Disorders, 19, 80-88.

하지완, 심현섭(2011a). 경-중도 한국어 실어증 환자의 어휘인출결함 진단에 연결주의(connectionism) WebFit 프로그램의 적용. 언어청각장애연구,

16, 231-247.

하지완, 심현섭(2011b). 어휘인출과 구어동반 제스처의 관계. 인지과학, 22, 123-143. 